\title{
BISKUIT CHOHI SEBAGAI ALTERNATIF UNTUK PERBAIKAN GIZI BALITA DAN IBU HAMIL PADA MASYARAKAT NELAYAN DI DESA PERCUT KECAMATAN PERCUT SEI TUAN
}

\author{
Zulhaida Lubis ${ }^{1}$, Syarifah $^{2}$, Erna Mutiara ${ }^{3}$, Juanita $^{4}$, Sri Novita Lubis ${ }^{5}$ \\ ${ }^{12345}$ Fakultas Kesehatan Masyarakat Universitas Sumatera Utara
}

\begin{abstract}
Abstrak
Ikan cohi-cohi merupakan campuran berbagai jenis ikan kecil-kecil, yang biasa dijadikan makanan bebek. Sementara di Desa Percut Sei Tuan masih dijumpai kasus kekurangan gizi pada balita dan ibu hamil. Ukan chohi dapat dijadikan campuran untuk pembuatan biskuit yang dapat membantu perbaikan gizi.

Melihat kenyataan tersebut, tim pengabdian ini ingin mengajak masyarakat untuk memanfaatkan limbah udang dan ikan cohi-cohi menjadi makanan bergizi bagi masyarakat sehingga dapat membantu menyelesaikan masalah kekurangan gizi pada balita dan ibu hamil.

Kegiatan ini dilakukan dalam beberapa tahap : dimulai dari sosialisasi pada masyarakat di Desa Percut; Tim pengabdian mempersiapkan rencana pelatihan pembuatan biscuit dari ikan chhi, dimana ikan chohi dijadikan tepung dan diujicobakan nutuk formula yang tepat berdasarkan uji organoleptic (rasa, warna, tekstur dan aroma). Selanjutkan dilakukan pembentukan kelompok dan pelatihan. Atas inisiatif masyarakat terbentuk kelompok CHOHI, dan dilakukan pelatihan pembuatan tepung dan biskuit.
\end{abstract}

Keywords: gizi balita, ibu hamil, ikan chohi

\section{PENDAHULUAN}

Masalah gizi pada balita seringkali merupakan bagian dari siklus masalah gizi yang diawali dari masalah gizi masa kehamilan. Kurang Energi Kronis (KEK) dan anemia merupakan masalah kekurangan gizi yang masih banyak dialami oleh ibu hamil. Hasil Riskesdas tahun 2013 menunjukkan 24,2 persen ibu hamil mengalami KEK, bahkan 38,5 persen terjadi pada wanita hamil yang berusia 15-19 tahun, dan 30,1 persen pada wanita hamil usia 2029 tahun (Kemenkes, 2013). Berbagai hasil studi menunjukkan bahwa faktor ekonomi menjadi faktor yang mendasar penyebab terjadinya gizi kurang dan gizi buruk di masyarakat (Unicef, 1998 dalam Soekirman, 2000; Balitbang Kota Medan, 2011). Kondisi ekonomi yang rendah menyebabkan keluarga tidak mampu menyediakan makanan bergizi bagi anggota keluarga. Bila terjadi dalam waktu yang lama akan berdampak pada kekurangan gizi dan yang paling rentan mengalaminya adalah kelompok anak balita dan ibu hamil. mengalaminya adalah kelompok anak balita dan ibu hamil.
Gizi yang baik sangat dibutuhkan bagi seorang ibu hamil. Karena makanan yang dikonsumsi ibu bukanlah untuk ibu sendiri tetapi juga diasup oleh bayi. Penataan gizi pada ibu hamil bertujuan untuk kecukupan kalori, protein, vitamin, mineral dan cairan untuk memenuhi kebutuhan zat gizi ibu, janin, serta plasenta. Perencanaan gizi untuk ibu hamil berbeda dengan ibu yang tidak hamil, kebutuhan ibu hamil akan protein meningkat sampai $68 \%$, asam folat $100 \%$, kalsium $50 \%$, zat besi $200-300 \%$. Bahan pangan yang dibutuhkan harus meliputi enam kelompok, yaitu makanan yang mengandung protein (hewani dan nabati), susu dan olahannya, roti dan bijian, buah dan sayur yang kaya akan vitamin $\mathrm{C}$, sayur berwarna hijau tua, buah dan sayur lainnya (Arisman, 2009).

Desa Percut kecamatan Percut Sei Tuan kabupaten Deli Serdang merupakan desa pinggir laut berbatasan dengan kota Medan, sebagian besar masyarakatnya bekerja sebagai nelayan yang umumnya berpenghasilan rendah atau tergolong miskin. Dari survei pendahuluan yang dilakukan di desa tersebut ditemukan ikan cohi-cohi berupa campuran berbagai jenis 
ikan kecil-kecil, yang biasa dijadikan makanan bebek. Melihat kenyataan tersebut, tim pengabdian ini ingin mengajak masyarakat untuk memanfaatkan limbah udang dan ikan cohi-cohi menjadi makanan bergizi bagi masyarakat sehingga dapat membantu menyelesaikan masalah kekurangan gizi pada balita dan ibu hamil.

\section{METODE PELAKSANAAN}

Berdasarkan hasil observasi di Desa Percut Kecamatan Percut Sei Tuan yang merupakan desa nelayan. Di desa nelayan tersebut banyak ikan cohi (campuran berbagai jenis ikan kecil-kecil) yang biasa dibuang atau dijadikan makanan bebek.

Berdasarkan hasil diskusi dengan masyarakat, ada keinginan kader maupun ibu untuk mengembangkan usaha lain yang dapat meningkatkan ekonomi dan status kesehatan balita dan ibu hamil.

\section{HASIL DAN PEMBAHASAN}

\section{Pelaksanaan}

Pelaksanaan kegiatan pengabdian masyarakat ini dilakukan melalui beberapa tahapan kegiatan. Adapun kegiatannya adalah sebagai berikut :

\section{Sosialisasi Kegiatan Pengabdian Masyarakat \\ Tim pelaksana pengabdian pada} masyarakat melakukan sosialisasi kegiatan pengabdian masyarakat di Lingkungan 3 Desa Percut pada hari Kamis, 15 September 2016. Kegiatan sosialisasi ini dihadiri oleh kepala Desa Percut, kader kesehatan, dan masyarakat Desa Percut. Adapun tujuan kegiatan ini dilaksanakan untuk menyampaikan tujuan dari kegiatan pengabdian pada masyarakat. Tujuan dari kegiatan pengabdian ini adalah untuk meningkatkan gizi balita dan ibu hamil yang ada di Desa Percut melalui pemanfaatan potensi sumber daya yang ada di desa tersebut yaitu ikan cohi. Selama ini ikan cohi tersebut hanya digunakan untuk makanan ternak, bahkan terkadang masyarakat desa membuangnya karena mereka tidak memiliki pengetahuan dan keterampilan untuk mengolah ikan cohi tersebut. Tim menjelaskan kepada peserta sosialisasi menganai kandungan gizi yang terdapat pada ikan cohi.

Di samping itu, kegiatan pengabdian ini juga diharapkan dapat memberdayakan ekonomi keluarga masyarakat Desa Percut melalui peningkatan keterampilan masyarakat untuk membuat olahan dari ikan cohi. Keterampilan tersebut berupa pembuatan tepung dan biskuit ikan cohi. Masyarakat dapat menjual biskuit ikan cohi tersebut di warung-warung yang ada di Desa Percut maupun luar Desa Percut, memasarkan di Tempat Pelelangan Ikan (TPI) karena banyak pengunjung dari luar Desa Percut yang datang ke TPI dan Resataurant Terapung yang menjadi objek wisata kuliner di wilayah tersebut. Berikut kegiatan sosialisasi yang telah dilaksanakan di Desa Percut.

\section{Persiapan Pelatihan}

Sebelum pelatihan dilaksanakan, tim pengabdian pada masyarakat melakukan persiapan terlebih dahulu. Kegiatan persiapan pelatihan ini dilaksanakan pada tanggal 16 September - 27 Oktober 2016. Adapun persiapan pelatihan sebagai berikut. Pengumpulan ikan cohi

Tim mengumpulkan ikan cohi dari masyarakat Desa Percut untuk dibuat menjadi tepung.

Pengolahan tepung ikan cohi

Ikan cohi yang sudah dikumpulkan kemudian dibersihkan dan dikeringkan. Proses pengeringannya dengan menjemur di bawah matahari kemudian dikeringkan kembali di oven. Setelah itu, dihaluskan menjadi tepung.

Percobaan biskuit

Tepung ikan cohi yang sudah dihasilkan kemudian dibuat menjadi biskuit. Dilakukan beberapa kali percobaan untuk menentukan komposisi dan takaran yang tepat sehingga dihasilkan biskuit ikan cohi yang memiliki rasa, tekstur, dan aroma yang disukai.

Uji organoleptik

Dilakukan uji organoleptik (uji kesukaan) pada biskuit ikan cohi. Uji ini dilakukan pada mahasiswa Fakultas Kesehatan Masyarakat USU.

\section{Pembentukan Kelompok}

$\begin{array}{ccc}\text { Setelah didapatkan } & \text { komposisi } \\ \text { biskuit ikan cohi maka dilakukan }\end{array}$


Zulhaida Lubis. et al. Biskuit Chohi Sebagai Alternatif Untuk Perbaikan Gizi Balita dan Ibu Hamil Pada...

pembentukan kelompok pada tanggal 28 Oktober 2016. Pada pembentukan tersebut dihadiri oleh masyarakat dan kader kesehatan. Terbentuk 1 kelompok yang terdiri dari 12 orang. Kelompok yang sudah terbentuk ini kemudian di buatkan Surat Keputusannya oleh kepala Desa Percut.

\section{Pelatihan Pembuatan Tepung dan Biskuit Ikan Cohi}

Pelatihan dilaksanakan pada tanggal 1 November 2016. Pelatihan dihadiri oleh seluruh anggota kelompok sebanyak 12 orang. Semua anggota kelompok dengan antusias mengikuti pelatihan. Hal ini terlihat dari keterlibatan aktif dari anggota kelompok dalam pembuatan adonan, pencetakan biscuit dan membakar dalam oven. Pada saat pelatihan juga diberikan 1 set oven beserta 1 buah tabung gas kepada kelompok tersebut. Tepung cohi yang sudah dihasilkan kemudian dibuat menjadi biskuit cohi. Dijelaskan mengenai komposisi untuk membuat biskuit.

\section{Monitoring Kelompok}

Monitoring dilakukan untuk mengetahui apakah ada kendala-kendala yang dialami oleh anggota kelompok setelah mengikuti kegiatan pelatihan. Sesuai perencanaan monitoring dilakukan 2 kli setelah pelatihan pembuatan biscuit. Hasil monitoring menunjukkan bahwa kelompok yang terbentuk sudah mulai merencanakan kerja kelompok membuat tepung ikan dan biskuit ikan cohi. Bahkan kelompok tersebut sudah melaporkan pekerjaannya ke kepala desa dan mendapat tanggapan yang baik dari kepala desa. Hal ini ditunjukkan dari permintaan kepala desa agar kelompok tersebut membuat proposal untuk pengajuan pengembangan kegiatan mereka menjadi unit usaha.

\section{Pemasangan Plang Pengabdian Pada Masyarakat}

\section{Uji Kandungan Gizi Biskuit Cohi}

Dilakukan pengujian terhadap kandungan biskuit cohi di Laboratorium PPKS Medan. Kandungan gizi yang diperiksa adalah karbohidrat, lemak, protein, kalsium, zinc, dan besi.

\section{KESIMPULAN DAN SARAN}

\section{Kesimpulan}

Terbentuk kelompok masyarakat untuk pemanfaatan ikan chohi sebagai bahan pangan yang bias membantu perbaikan gizi. Melalui pelatihan pengetahuan dan keterampilan masyarakat mengenai pemanfaatan ikan chohi sebagai makanan tambahan dalam rangka perbaiakan gizi.

\section{Saran}

Kegiatan pada kelompok CHOHI dapat direplikasi di desa nelayan lainnya dengan mendapat dukungan dari kepala desa setempat.

\section{DAFTAR PUSTAKA}

Abun. 2009. Pengolahan Limbah Udang Windu Secara Kimiawi Dengan $\mathrm{NaOH}$ dan $\mathrm{H}_{2} \mathrm{SO}_{4}$ Terhadap Protein dan Mineral Terlarut. Jurusan Nutrisi dan Makanan Ternak Fakultas Peternakan Universitas Padjadjaran .Jatinangor.

Arisman, MB, 2004. Gizi dalam Daur Kehidupan. Jakarta. EGC

Balitbang Kota Medan. 2011. Kajian Keberadaan Gizi Buruk di Kota Medan. Badan Penelitian dan Pengembangan Kota Medan.

SDKI. 2012. Survei Demografi dan Kesehatan Indonesia (SDKI).

Depkes RI. 2010. Riset Kesehatan Dasar (Riskesdas). Badan Penelitian dan Pengembangan Departemen Kesehatan RI. Jakarta.

Kemenkes RI. 2013. Riset Kesehatan Dasar (Riskesdas). Badan Penelitian dan Pengembangan Kementerian Kesehatan RI. Jakarta.

Mirzah, Yumaihana dan Filawati. 2006, Pemakaian Tepung

Limbah Udang Hasil Olahan Sebagai Pengganti Tepung Ikan Dalam Ransum Ayam Broiler.Jurusan Nutrisi dan Makanan Ternak Fakultas Peternakan Universitas Andalas. Padang. Sumatra Barat. 
Zulhaida Lubis. et al. Biskuit Chohi Sebagai Alternatif Untuk Perbaikan Gizi Balita dan Ibu Hamil Pada...

Purwatiningsih. 1990. Isolasi Khitin dan

Komposisi Kimia dari Limbah Udang

Windu. Tesis Pascasarjana. ITB. Bandung. 